\title{
СУЧАСНА ПАРАДИГМА ДОСЛІДЖЕНЬ ІНФОРМАЦІЙНИХ ПРОЦЕСІВ ТА ЯВИЩ У СУСПІЛЬНИХ НАУКАХ: ВСТУП ДО СОЦІОГУМАНІТАРНОЇ ІНФОРМОЛОГІї
}

\section{Бєляков К. I.}

\section{ВСТУП}

Аналіз сучасних наукових досліджень стану та структури наукових знань про інформаційні процеси, явища, діяльність та суспільні відносини, що при цьому виникають, показує повну відсутність єдиного підходу до їх структуризації. Така ситуація зумовлена проблемами процесів глобалізації та інформатизації, зміною наявної загальної системи наукових і практичних уявлень про інформацію, інтенсивного переходу суспільства від індустріального до інформаційного укладу, формуванням нової інформаційної парадигми. Не $є$ винятком соціальні та гуманітарні науки. Розвиток наукових знань та відповідних досліджень вступає в таку стадію, коли між ними підсилюються взаємозв'язки та взаємопроникнення.

\section{1. Парадигма науки}

Нагадаємо, що під парадигмою прийнято розуміти «сукупність філософських, загальнотеоретичних основ науки; система понять i уявлень, які властиві певному періодові розвитку науки, культури, цивілізації» ${ }^{1}$.

По-перше, це найбільш загальна картина раціонального упорядкування природи, деякий мінісвітогляд. По-друге, це дисциплінарна матриця, що характеризує сукупність переконань, цінностей, технічних засобів і т. ін., що об'єднують вчених у наукове співтовариство. Потрете, це загальновизнаний зразок, шаблон для розв'язання мудрокрутів. Історія науки - це конкурентна боротьба наукових співтовариств, що супроводжується зміною парадигм. Панування парадигми - це період «нормальної науки», що завжди закінчується «вибухом парадигми зсередини» ${ }^{2}$. Таким чином, парадигма виступає як особливий спосіб організації наукового знання, що визначає те чи інше бачення світу. «Вона містить нерозв'язані питання, тобто відкриває

${ }^{1}$ Бибик С.П., Сюта Г.М. Словник іншомовних слів: тлумачення, словотворення та слововживання. Харків : Фоліо, 2006. С. 415.

${ }^{2}$ Kuhn T. The Structure of Scientific Revolutions. Chicago University of Chicago press, 1962. 
простір для досліджень. Парадигма не є чимось статичним, застиглим. На іiі основі проводяться дослідження, в результаті котрих парадигму переформовують, уточнюють» ${ }^{3}$.

Сучасна парадигма інформації, за розумінням вітчизняного філософа Т. Геращенко, класифікується так: «1. Системні науки про інформацію (теорія інформації, кібернетика, загальна теорія систем). 2. Когнітивні науки (теорія штучного інтелекту, семіотика, лінгвістика (нейролінгвістика, психолінгвістика, обчислювальна лінгвістика), психологія (нейропсихологія, обчислювальна психологія, когнітивна психологія), нейрофізіологія, антропологія (когнітивна антропологія, антропологічна лінгвістика), філософія (теорія пізнання). 3. Соціотехнічні науки - інформатика, програмування, науки про комунікацію i зв'язки, науки про управління, соціологія знання, економіка (економічні питання інформації і знання)» ${ }^{4}$.

Бачиться, що надане автором трактування класифікації «наук про інформацію» $€$ не повною мірою коректним.

В авторському розумінні інформатики мають місце певні й першочергові проблеми. Почнемо з останньої (третьої) категорії. Йдеться про те, що авторка не визначає, яку інформатику має на увазі - теоретичну, технічну, соціальну, історичну, згідно з класифікацією сучасних наукових знань, що діють в Україні після реформи (яка, до речі, теж є нині досить сумнівною), чи інформатику, що викладається у школі, тобто «комп'ютерну грамотність». Але ж зарахування інформатики до соціотехнічних наук залежить від визначення ії різновиду. Останнім часом говорять й про економічну, історичну, військову, правову, криміналістичну та інші «інформатики». Щодо економіки, якщо вона розглядається як наукове знання, а не як галузь господарства, то вона $є$ сукупністю низки економічних наук, а «економічні питання інформації $\mathrm{i}$ знання» стосуються скоріше економічної інформатики.

Коли йдеться про програмування та «науки про комунікацію i зв'язки» (в їх математичному та технологічному змісті розумінні), на нашу думку, це категорії кібернетики та іiї напрямів (наприклад, теорії комунікацій). Категорія «керування» (можливо, більш коректним буде використання терміна «управління») також потребує уточнення. Загальноприйнято, що управління як категорія кібернетична може здійснюватися в біологічних, технічних та соціальних системах.

\footnotetext{
${ }^{3}$ Чуйко В.Л. Рефлексія основоположень методологій філософії науки. Київ : Центр практичної філософії науки. 2000. С. 193.

${ }^{4}$ Геращенко Т.Г. Філософсько-методологічний аналіз сучасної парадигми інформації : дис. ... канд. філос. наук : 09.00.09 / Сумський державний педагогічний університет ім. А.С. Макаренко. Суми, 2003. С. 59.
} 
Ці процеси вивчаються, відповідно, біологією, кібернетикою та теорією соціального управління. Соціологія знання як наука викликає певні сумніви. Принаймні нам відома соціологія, в якій започатковуються, як і у всякому науковому напрямі, нові теорії та концепції, хоча вивчення феномена «знання», навіть із точки зору досліджування його у соціальному змісті (соціальні знання), за наданим переліком, було б доречно зарахувати до предмета вивчення «когнітивних наук».

Мабуть, можна дискутувати й щодо складу перших двох зазначених груп - системних наук про інформацію та когнітивних наук. Хоча актуальність «мультідисциплінарних» наукових знань нині безумовна.

Наведений приклад ще раз свідчить про відсутність єдності розуміння структури наукових знань про інформацію. Такий стан у сучасному наукознавстві не може не впливати на формування «інформаційних» наук у межах соціогуманітарних досліджень.

Однак фахівці, принаймні вітчизняні, які досліджують питання місця інформації в суспільних науках, сутності інформаційної діяльності, впливу інформаційних процесів на суспільство на міжгалузевому рівні i, нарешті, правовим регулюванням сфери інформаційних відносин чомусь рідко звертаються до проблем класифікації та структури «наук про інформацію» в соціогуманітарному секторі наукових знань, що дійсно мають суто теоретико-методологічний (загальнонауковий) характер, але мають велике практичне значення для подальшого розвитку науки загалом.

Нині превалюють практичні підходи - як до законодавчого регулювання сфери інформаційних відносин (формування інформаційного законодавства), так і до проблем впровадження та використання здобутків науково-технічного прогресу в управлінську діяльність (створення спеціалізованих інформаційних систем), а також із питань організаційно-правових та технологічних заходів протидії негативним явищам, що відбуваються в суспільстві через неправомірне використання інформаційних технологій, захисту інформації і т. ін.

В той же час відомо, що розвиток будь-якої науки має подвійну зумовленість. По-перше, необхідно, щоб науково-теоретичні підгрунтя дослідження в цій галузі знань були безперервними, розвивалися по наростаючій, а по-друге, щоб наукові досягнення впроваджувалися в реальну соціальну практику відповідної сфери людської діяльності. Але все це можливе лише за наявності певного масиву знань у науковій галузі. Стосовно процесу розвитку соціогуманітарних «інформаційних» напрямів, то такими $€$ на часі знання методів та засобів математики, кібернетики, інформатики, інформаційних технологій та ряду інших, а також формування відповідного термінологічно-понятійного апарату зазначених наук (аксіоматики) в соціальні напрями досліджень. 


\section{2. Інтеграція та диференціація наукових знань: \\ теорія і практика}

Характерною особливістю сьогодення $є$ помітне поглиблення інтегративних процесів у науці й усієї соціальній практиці (разом із розвитком діалектичне протилежної тенденції - диференціації).

Диференціація та інтеграція наукових пошуків перебувають у діалектичній єдності, в єдності й боротьбі протилежностей роз'єднання та об'єднання. Ці протилежності взаємозумовлюють, утримують та доповнюють один одного. Диференціація розуміється як процес поділу науки на ряд спеціалізованих напрямів, їх виділення у самостійні розділи знань. Інтеграція, натомість, становить синтез наук на основі їх взаємозв'язку, взаємопроникнення і взаємодії їхніх методів, ідей, теорій.

Формально диференціація, що веде до специфікації та індивідуалізації напрямків науки із своїми поняттями, засобами та мовою, $\epsilon$ шляхом до відособлення наукової галузі, міжнаукового розмежування. Це твердження $є$ обгрунтованим у процесі превалювання тенденцій до розподілу і самозамикання, розриву міжнаукових зв'язків, відірваності понятійної та аксіоматичної бази науки від інших наукових систем. Але водночас це судження $\epsilon$ суперечливим, оскільки диференціація здійснюється через інтеграцію, несе в собі елементи інтеграції і $€$ необхідною умовою розвитку науки загалом.

Для інтеграції множини наук, що мають соціогуманітарний зміст, в одне системне утворення необхідна спільна «наукова платформа», якою $є$ феномен інформації та відповідні ресурси. Так, не виникає сумнівів, що інформаційні процеси, явища та виникаючі при цьому суспільні відносини становлять предмет дослідження філософії, державного управління, політології, соціології, соціальних комунікацій, психології, педагогіки i, нарешті, права. Більш конкретно зазначений предмет виявляється в дослідженнях за окремими спеціальностями зазначених напрямів наукових пошуків.

Р. Нугаєв влучно зазначає, що «історія науки може розглядатися як історія постійно флуктуючих, віртуальних теоретичних і експериментальних практик, що зароджуються i зникають» ${ }^{5}$. До історикопорівняльного аналізу використання здобутків науково-технічного прогресу в соціогуманітарних науках ми неодноразово зверталися раніше ${ }^{6,7}$.

${ }^{5}$ Нугаев Р.М. Смена базисных парадигм: концепция коммуникативной рациональности. Вопросы философии. 2001. № 1. С. 114.

${ }^{6}$ Бєляков К.І. Інформатизація в Україні: проблеми організаційного, правового та наукового забезпечення : монографія. Київ : КВІЦ, 2008. С. 144. 
Яскравим прикладом процесів інтеграції та диференціації наукових знань останніх років в Україні є «реформа науки» 2015 року, яка, на думку більшості науковців, була зумовлена лише політичними аргументами, тобто бажанням внесення будь-яких змін окремими суб'єктами владних структур - «реформа заради реформ». Йдеться про Постанову Кабінету міністрів України ${ }^{8}$, ніби зумовлену новою редакцією Закону «Про вищу освіту» та ініційовану МОН України. Як наслідок, з'явився Наказ МОН «Про особливості запровадження переліку галузей знань i спеціальностей, за якими здійснюється підготовка здобувачів вищої освіти ....» ${ }^{9}$. Вивчення додатку до наказу, яким $є$ «Таблиця відповідності переліку наукових спеціальностей (2011 р.) та переліку галузей знань і спеціальностей, за якими здійснюється підготовка здобувачів вищої освіти (2015)» ${ }^{10}$, показало не тільки повну неузгодженість у теоретико-методологічному контексті, а й порушення принципів науково-історичної та культурної спадщини.

\section{3. Соціогуманітарна інформологія: мультидисциплінарний напрям наукових досліджень}

Свого часу на рівні дисертаційного дослідження нами було наголошено на необхідності формування інноваційного наукового напряму в юридичній науці - правничої інформаціології «... як міжгалузевого наукового напряму, головним завданням якого повинно стати поєднання знань про інформацію (правової інформатики, інформаційного права, інформаційного менеджменту та ін.) в межах правової науки, практики і теорії управління» ${ }^{11}$.

${ }^{7}$ Бєляков К.І., Золотар О.О. Суспільно-гуманітарні наукові дослідження в Україні: інформаційний вимір. Modern researches: progress of the legislation of Ukraine and experience of the European Union: Collective monograph. Part 1. Riga: Izdevniecība «Baltija Publishing», 2020. C. 363-397.

${ }^{8}$ Про затвердження переліку галузей знань і спеціальностей, за якими здійснюється підготовка здобувачів вищої освіти : Постанова Кабінету міністрів України від 29 квітня 2015 р. № 266. URL: https://zakon.rada.gov.ua/laws/show/ru/2662015-\%D0\%BF.

${ }^{9}$ Про особливості запровадження переліку галузей знань і спеціальностей, за якими здійснюється підготовка здобувачів вищої освіти, затвердженого постановою Кабінету Міністрів України від 29 квітня 2015 року № 266: Наказ МОН від 06.11.2015 p. № 1151. п. 2.3. URL: https://drive.google.com/file/d/0B3m2TqBM0A PKNzMxU1FPbE9pa2M/view

${ }^{10}$ Див.: URL: https://drive.google.com/file/d/0B3m2TqBM0APKbk5HMzZ3UjJz $\mathrm{STQ} /$ view

${ }^{11}$ Бєляков К.І. Організаційно-правове та наукове забезпечення інформатизації в Україні: проблеми теорії та практики : дис. ... д-ра юрид. наук: 12.00 .07 / Ін-т держави і права ім. В.М. Корецького НАН України. Київ, 2009. С. 367-368. 
Вихідним пунктом запропонованого напряму була гіпотеза, що «сучасні суспільно-правові відносини мають інформаційно-комунікативний характер, а будь-які відносини, у тому числі й інформаційні, здійснювалися, здійснюються й будуть здійснюватися як комунікація. Тому основним об'єктом уваги правничої інформаціології $\epsilon$ інформаційно-комунікативні зв'язки в правничій діяльності та соціальному управлінні, тобто інформаційно-правова реальність» ${ }^{12}$.

Поряд із цим у сучасній науці доктринально виділено науковий напрям «інформологія» - це узагальнена назва наук про інформацію. Термін «інформологія» походить від латинського informatio «пояснення, виклад, тлумачення, поняття» і грецького $\lambda$ оүо - «слово, знання, вчення». Об'єктом дослідження інформології $\epsilon$ інформація. В наукознавстві розглядається теоретична та прикладна інформологія.

До прикладної інформології зараховують: теорію інформації information theory (застосування інформології до кібернетики), інформатику - informatics (застосування інформології до комп'ютерної техніки та програмування), теорію масової інформації (застосування інформології до ЗМІ й журналістикознавства), інформаційні вимірювання мови (застосування інформології до лінгвістики), науково-технічну інформацію - scientific information (застосування інформології до науково-технічної літератури), представлення знань knowledge science (застосування інформології до теорії штучного інтелекту), інформаційні вимірювання в генетиці - bioinformatics (застосування інформології до генетики), пошук інформації information retriaval (застосування інформології до документознавства, зокрема до бібліотекознавства, архівознавства, баз даних, в том числі й Інтернет), а також ціла низка інших аналогічних застосувань: у суспільствознавстві (питання інформаційного суспільства - information society), доступності інформації (information access), інформаційного менеджменту (information managment), інформаційної безпеки (information secyrity), інформаційної будови (архітектури) різних об'єктів (information architecture) та ін. Розглядаються також філософські напрями інформології: антропоцентричний, атрибутивний та кібернетичний підходи до інформації. Цей перелік розділів прикладної інформології $є$ неповним і постійно розширюється ${ }^{13}$.

На підставі вищезазначеного з метою реалізації процесу інтеграції досягнень соціогуманітарних наукових знань про інформацію в одне

\footnotetext{
12 Бєляков К.І. Антологія «інформаційних» наук в юриспруденції / Держава і право. 2005. Вип. 30. С. 269-278.

${ }^{13}$ Інформологія. Вікіпедія - вільна енциклопедія. URL: https://uk.wikipedia.org/ wiki/ Інформологія
} 
ціле видається обгрунтованим запропонувати напрям наукових досліджень, який ми визначаємо як «соціогуманітарну інформологію» (Socio-humanitarian informology) - інтегрований, міждисциплінарний напрям наукових досліджень, щчо має поєднати групу соціальних та гуманітарних галузей знань та спеціальностей, предметом дослідження яких є соціально значущі інформащійні процеси та явища, відповідні зв'язки та відносини в суспільстві ${ }^{14}$.

У цій інституції науки усі об'єкти та процеси дослідження мають інформаційне подання і опис, тому вона вважає кожен процес дослідження інформаційним, а знання - елементами єдиної узагальненої системи знань про інформацію.

Змістом запропонованого мультидисциплінарного напряму наукового пошуку повинні стати фундаментальні та прикладні комплексні, міжгалузеві наукові дослідження 3 юридичного, економічного, технологічного і соціального забезпечення інформаційних відносин, процесів інформатизації суспільства та управління ними.

Основними напрямами досліджень у цьому інноваційному напрямі мають стати: теоретико-методологічні, організаційні, правові та технологічні основи регулювання суспільних інформаційних відносин і процесу інформатизації адміністративної діяльності; дослідження в галузі соціальних проблем інформатизації суспільства; формування теоретичних засад розробки методів i засобів інформаційного забезпечення, а також підтримка прийняття рішень у сфері людської діяльності на основі інформаційних технологій; розробка наукових основ, формування концепцій та проєктів функціонування інформаційних ресурсів, їх адаптація в національному та міжнародному інформаційному просторі; розвиток і становлення термінологічнопонятійного апарату (аксіоматіки), розробка класифікаторів, тезаурусів, термінологічних словників щодо інформаційних відносин; становлення системи уніфікації соціальної інформації та інше.

Однак, усвідомлюючи складність формування нового напряму наукових досліджень, мабуть, необхідно окреслити межі предмета соціогуманітарної інформології, до якого пропонується зарахувати здобутки наукового пошуку в межах інформаційних процесів i соціальних явищ в окремих галузях знань і спеціальностей за легітимним нині в Україні їх переліком ${ }^{15}$.

${ }^{14}$ Енциклопедія соціогуманітарної інформології (Том 1) / коорд. проекту проф. К.І. Бєляков. Київ : Видавничий дім «Гельветика», 2020. Т. 1. 472 с.

${ }^{15}$ Про затвердження переліку галузей знань і спеціальностей, за якими здійснюється підготовка здобувачів вищої освіти : Постанова Кабінету міністрів України від 29 квітня 2015 р. № 266. URL: https://zakon.rada.gov.ua/laws/show/ru/2662015-\%D0\%BF. 
Мабуть, «системоутворюючою» галуззю має бути «право» (08) та спеціальність «право» (081). Підгрунтям соціогуманітарних досліджень $\epsilon$ також «Гуманітарні науки» (03), за спеціальностями - «Філософія» (033), «Філологія» (035), «Соціальні та поведінкові науки» (05) «Економіка» (051), «Політологія» (052), «Психологія» (053), «Соціологія» (054). До переліку, що пропонується, можна додати дослідження в галузі «Освіта» (01), «Журналістика» (06) «Журналістика» (061); «Управління та адміністрування» (07) - «Облік і оподаткування» (071), «Менеджмент» (073), «Маркетинг» (075).

Безумовно, чільне місце в контексті формування термінологічнопонятійного апарату мають зайняти знання в галузі «Інформаційні технології» (12) - «Комп'ютерні науки» (122), «Кібербезпека» (125), «Інформаційні системи та технології» (126).

Не обійтися без досліджень у галузі «Воєнні науки, національна безпека, безпека державного кордону» (25) - «Національна безпека» (256) (в контексті інформаційної безпеки як ії складника).

«Спадкоємцями» галузі науки «державне управління», де безліч напрямів пов'язані 3 інформатизацією державної служби та адміністративних послуг, є галузі знань «Управління та адміністрування» (07) - «Облік і оподаткування» (071), «Менеджмент» (073), «Маркетинг» (075).

Під час процесів інформатизації та глобалізації не обійтися й без галузі «Міжнародні відносини» (29) - «Міжнародні відносини, суспільні комунікації та регіональні студії» (291), «Міжнародне право» (293).

\section{ВИСНОВКИ}

Аналіз положень наукознавства та історії розвитку наукових пошуків в напрямі дослідження інформаційних процесів та явищ, а також їхнього впливу на суспільне життя показує відсутність єдиного бачення структури наукових знань. Такий стан не може негативно не впливати на формування теоретико-методологічної бази інформатизації в Україні, побудови інформаційного суспільства.

3 точки зору організації наукової діяльності з боку держави, що реалізується в межах законодавчого регулювання відносин у цій сфері, то нині спостерігаються негативні тенденції. Йдеться про реформи, зумовлені, мабуть, більш політичними процесами, ніж державними інтересами в напрямі розвитку національної науки, всупереч принципам науково-історичної та культурної спадщини, що веде до теоретико-методологічної неузгодженості галузевих досліджень та зниження якості атестації наукових кадрів. 
Першочерговим організаційним кроком на рівні державного управління науковою діяльністю має стати перегляд структури галузей знать із метою їх диференціації за відповідними спеціальностями.

3 позицій наукового забезпечення інформатизації країни в контексті інтеграції досягнень соціогуманітарних наукових знань про інформацію в одне ціле пропонується формування «Соціогуманітарної інформології» (Socio-humanitarian informology), яку ми визначаємо як інтегрований, міждисциплінарний напрям наукових досліджень, щчо має поєднати групу соціальних та гуманітарних галузей знань та спеціальностей, предметом дослідження яких є сочіально значущі інформачійні прочеси та явища, відповідні зв'язки та відносини в суспільстві.

Саме в межах запропонованого напряму має бути розроблений глосарій, який стане основою термінологічно-понятійного апарату відповідних досліджень, перший крок до якого вже зроблений в Енциклопедії соціогуманітарної інформології ${ }^{16}$.

Крім того, соціогуманітарні дослідження у сфері інформації потребують постійного моніторингу, що може бути реалізовано у створенні відкритого інформаційного ресурсу, наприклад, у формі відповідної бази даних дисертаційних досліджень за вказаними вище спеціальностями на окремому сайті в Інтернеті.

Ми впевнені, що запропонована інтеграція зазначених напрямів досліджень у «Соціогуманітарну інформологію» уможливить ефективне, науково обгрунтоване формування інформаційного суспільства в країні, подальше управління процесом інформатизації та оптимізацію інформаційного законодавства України.

\section{АНОТАЦІЯ}

На основі аналізу постулатів наукознавства розглянуто генезу, сучасний стан та перспективи розвитку соціогуманітарних напрямів наукового пошуку в напрямі інформаційних процесів та явищ у контексті організації наукових досліджень, зумовлених змінами в національному законодавстві у сфері освіти і науки.

Надане авторське бачення напряму інтеграції знань та досліджень інформаційних процесів, явищ і відносин в єдину наукову інституцію «Соціогуманітарну інформологію».

Запропоновані конкретні шляхи удосконалення організаційного та наукового забезпечення процесу формування у країні інформаційного суспільства - інформатизації України.

${ }^{16}$ Енциклопедія соціогуманітарної інформології (Т. 1)/ коорд. проекту проф. К.І. Бєляков. Київ : Видавничий дім «Гельветика», 2020. Т. 1. 472 с. 


\section{ЛІТЕРАТУРА}

1. Бибик С.П., Сюта Г.М. Словник іншомовних слів: тлумачення, словотворення та слововживання. Харків : Фоліо, 2006. С. 415.

2. Kuhn T. The Structure of Scientific Revolutions. Chicago University of Chicago press, 1962.

3. Чуйко В.Л. Рефлексія основоположень методологій філософії науки. Київ : Центр практичної філософії науки. 2000. С. 193.

4. Геращенко Т.Г. Філософсько-методологічний аналіз сучасної парадигми інформації : дис. ... канд. філос. наук : 09.00.09 / Сумський державний педагогічний університет ім. А.С. Макаренко. Суми, 2003. C. 59.

5. Нугаев Р.М. Смена базисных парадигм: концепция коммуникативной рациональности. Вопросы философии. 2001. № 1. С. 114.

6. Бєляков К.І. Інформатизація в Україні: проблеми організаційного, правового та наукового забезпечення : монографія. Київ: КВІЦ, 2008. C. 144

7. Бєляков К.І., Золотар О.О. Суспільно-гуманітарні наукові дослідження в Україні: інформаційний вимір. Modern researches: progress of the legislation of Ukraine and experience of the European Union: Collective monograph. Part 1. Riga : Izdevniecība «Baltija Publishing», 2020. C. 363-397.

8. Паспорти спеціальностей: Постанова президії ВАК України 8.10.2008 p. № 45-06.

9. Золотар О.О. Права і свободи людини: інформаційний вимір. IT-право: проблеми $і$ перспективи розвитку в Украӥні : збірник мат. наук.-прак. конф., м. Львів, 18 лист. 2016 р. Львів, 2016. С. 59-68.

10. Про затвердження переліку галузей знань і спеціальностей, за якими здійснюється підготовка здобувачів вищої освіти : Постанова Кабінету міністрів України від 29 квітня 2015 р. № 266. URL: https://zakon.rada.gov.ua/laws/show/ru/266-2015-\%D0\%BF.

11. Про особливості запровадження переліку галузей знань i спеціальностей, за якими здійснюється підготовка здобувачів вищої освіти, затвердженого постановою Кабінету Міністрів України від 29 квітня 2015 року № 266 : Наказ МОН від 06.11.2015 р. № 1151. п. 2.3. URL: https://drive.google.com/file/d/0B3m2TqBM0APKNzMxU1 $\mathrm{FPbE} 9 \mathrm{pa} 2 \mathrm{M} / \mathrm{view}$

12. Про затвердження примірного переліку та опису предметних напрямів досліджень в межах спеціальності 081 «Право» : Наказ МОН України від 28 грудня 2018 p. № 1477. URL: https://mon.gov.ua/ua/npa/ pro-zatverdzhennya-primirnogo-pereliku-ta-opisu-predmetnih-napryamivdoslidzhen-v-mezhah-specialnosti-081-pravo 
13. Бєляков К.І. Організаційно-правове та наукове забезпечення інформатизації в Україні: проблеми теорії та практики : дис. ... д-ра юрид. наук : 12.00.07 / Ін-т держави і права ім. В.М. Корецького НАН України. Київ, 2009. С. 367-368.

14. Бєляков К.І. Антологія «інформаційних» наук в юриспруденції. Держава і право. 2005. Вип. 30. С. 269-278.

15. Інформологія. Вікіпедія - вільна енщиклопедія. URL: https:// uk.wikipedia.org/wiki/Інформологія

16. Про затвердження переліку галузей знань і спеціальностей, за якими здійснюється підготовка здобувачів вищої освіти : Постанова Кабінету міністрів України від 29 квітня 2015 р. № 266. URL: https:// zakon.rada.gov.ua/laws/show/ru/266-2015-\%D0\%BF.

17. Енциклопедія соціогуманітарної інформології (Том 1)/ коорд. проекту проф. К.І. Бєляков. Київ : Видавничий дім «Гельветика», 2020. T. $1.472 \mathrm{c}$.

\section{Information about the author:}

Bieliakov K. I.,

Doctor of Juridical Sciences, Professor, Honored Worker of Science and Technology of Ukraine, Head of the Scientific Department of the Theory, History and Philosophy of Information Law, Scientific Research Institute of Informatics and Law of the National Academy of Legal Sciences of Ukraine

110B, Sacsaganskogo str., Kyiv, 01032, Ukraine 